\title{
The Application of a Metaphor Technique by Healing Stories to Reduce Student Anxiety
}

\author{
Titin Indah Pratiwi, Nita Jemiparera \\ Department of Guidance and Counseling \\ Universitas Negeri Surabaya \\ Surabaya, Indonesia \\ titinindahpratiwi@unesa.ac.id
}

\begin{abstract}
The background of this research is the discomfort feeling of some students during their communication with others since they have problems with their self confidence. This problem must be solved because it will make the students have difficulty in comunication in the future. Some techniques can be utilized for helping these studenta, one of them is a metaphor tehcnique. This paper presents the effectiveness of applying the metaphor technique in the form of healing stories to decrease the communication problems of students in the setting of counseling group design. One group pre-test and post-test design are used. Since the data is normally distributed, the technique for data analysis used in this research is a paired sample $t$ test. Results of analysis show that there is a difference of communication apprehension level before and after the metaphor technique in the form of healing stories hasbeen applied. On the other words, the application of metaphor technique in the form of healing stories can decrease the level of communication apprehension of the students.
\end{abstract}

Keywords-communication apprehension; metaphor; healing stories

\section{INTRODUCTION}

Many students have problems in communication. They feel uncomforted during communication (communication appre-hendsion) with their friends, teachers, or other persons [1]. Many of them afraid when their teacher ask them to do their assignment in front of the class, stress if they cannot answer the questions, and hesitate to give their opinion because they are afraid that the teacher will be mad. It is an obstacle for them in achieving study targets [1].

The same phenomenon has been experienced by some students of vocational high school Surabaya when they were interviewed for placement test to get industrial internship. It happened because they got negative stories from their seniors such that negative thinking arised and made them difficult to answer questions spoken, when the students are asked to talk in front of the class [2].

Moreover, some students had problem in communication with their friends. They feel not-confidence of their ability. This was because they have had negative experience in the form of unpleasant response from their friends and teachers.
The type of communication apprehension that has been explained above is called a situational communication apprehension. It is a situation in which the apprehension of a person increases when he or she got a special attention. For example, it is during an inter-view or when a negative thinking arises due to response from their friend [3].

This problem must be cared since it will cause more serious problems to the students. They will have difficulty in communication with their friend, in telling their opinion, and their study achievement will be decreased. One of the efforts is by using an intervention such that they feel comfortable and safe during their communication time. An intervention strategy can be a metaphor strategy [4].

The metaphor is usually in the form of analogy, parable, figurative, or story which are designed to teach new concepts that push counselees in deep understanding of themselves. This metaphor can be expressed verbally, books (bibliotherapy), drama, video (video therapy), play therapy, or humor [5].The metaphor strategy is providing in the form of healing stories. Healing stories is a collection of selected stories which can give learning or inspiration or model or example to counselees for develop a therapeutic changes [6]. This research is purposed to examine the affectivity of the metaphor strategy in the form of healing stories in a group counseling to reduce communication apprehension of students.

\section{METHODS}

It is a quantitative research with an experiment. The design of the research is one group pre-test and post-test. In this research, only one group experiment will be given treatments without a control group [7]. The one group pre-test and post test experiment design is used to observed the influence of the application of the metaphor technique in the form of healing stories in a group counseling to reduce communication apprehension of students. The research design is depicted in Figure 1.

$$
\mathrm{KE} \longrightarrow \mathrm{O} 1 \mathrm{X} \quad \mathrm{O} 2
$$

Figure 1. Research design. 
Remarks:
$\mathrm{KE}:$ An experiment group
O1 : Pre-Test
O2 : Post Test
$\mathrm{X}$ : the metaphor technique of Healing Stories

Procedure:

1. Choose 4 students of class $X$ who have high level of communication apprehension through a pre-test

2. Treat students (a group counseling by the metaphor technique of Healing Stories) for 6 times, once a week with the duration of \pm 45 minutes

3. After the intervention, do a post-test

4. Compare the scores of pre-test and post-test

\section{RESULTS AND DISCUSSION}

The results of a paired sample $t$ test is that the value of 2tailed is $0.014<0.05$. It means the $\mathrm{H} 0$ is rejected and $\mathrm{H} 1$ is accepted. Therefore, there is a difference of communication apprehension of students before and after the treatment using the metaphore technique of healing stories.

Analysis to the pre-test results to 60 class $\mathrm{X}$ students shows that 4 students are categorized as high commu-nication apprehension problem. They are then treated by using the metaphor techniques of healing stories. After the treatment, the student do post-test. The results of pre and post-test then are tested by a non-parametric statistical; i.e. paired sample $t$ test to examine the hypo-thesis.

The results of paired sample t test provides $\rho=0.014$ that is less than the signicant level $\alpha=0.05$ that means $\mathrm{H} 0$ is rejected and $\mathrm{H} 1$ is accepted. Ho (Nul-hypothesis) states that "there is no difference of the communication apprehension of students before and after the metaphor technique of healing stories applied for treatment". It shows that the group counseling gives difference in communication apprehension of students before and after the metaphor technique of healing stories applied for treatment. The difference is in the positive way; i.e. the decrease in communication apprehension after the treatment. Therefore, the $\mathrm{H} 1$ that states "There is a difference in communication apprehension between before and after that treatment using the metaphor technique" is proven.

One of factor that influencing communication apprehension is gender. Women have higher level of communication apprehension compare to men. It is because momen are more sensitive dan susceptible to negative response from others compare to men. It can cause to their self confidence.

It is comparable to the results score of pre-test and posttest in this researh in which the women subject have higher score of com-munication apprehension than men.

The Concise Encyclopedia of Communication, that one feels high level of worry when they are too sensitive to the change of their envi-ronment, to negative response of others, and to think that they have low capability in speaking. This statement is relevant to this research, in which one of the subject $(\mathrm{WH})$ has communication apprehension since he feels insecure/ inferiority of himself and feels uncomfortable when he is in crowd [8]. TIS has low focus on the subject of his presentation such that he cannot discuss fluently because he feels that he has low capability. Subjects DSP and FF have the same problem in communication. Therefore, it can be said that the source of their worry is the negative perception to other response and to their own capability.

This worry gives negative effects such as avoid communicating and intercting to others, less participation in learning processes in the class room (group discussion). It causes the learning processes are not efective. The research found that the physical reaction of persons who feel worry is hand sweated, increased hearth rate, and leg trembling. Moreover, they sho-wed psychological reaction such as affraid to make mistake. not-calm, and cannot focus. The subject of this reseach whowed the same reac-tion as stated above. Each of them reacts psy-chologically in the different way.

The unsure or negative perception of an individual to ability of him or herself causes stress and worry. Unsure or negative perception to ability of him or herself is a part of individual cognitive that is called self efication. It is a belief to solve problems. Self efication of an individual is useful for training control to face stressor, which has important role in rising apprehension. An individual who is able to train control to face threat or stressor will have low level of apprehension, otherwise he or she will have high level of apprehension [9].

In this research the researcher must try to improve the self efication of the subjects to reduce their communication apprehension. It is through telling stories. The stories can be used as a symbolic model that can give explanation, information, and expe-rience for strenghten self efication of an individual [3]. The self efication can be obtained, learned, and improved from 4 sources of information. They are expe-rience of success, non-direct experience, ver-bal push, and psychological reaction. They are occations or stimulants that are useful to inspi-re or positive arousal for solving their problems. In this research, stimuly of healing stories is successful in reducing communication apprehension of subjects [10].

Three stories was provided in this research, they are (i) "Facing fear" that is purposed to push subject to be brave, (ii) "Develop self-confidence", that is purposed to reduce fear and worry; and (iii) "Facing change" that is purposed to push and motivate subject to build and develop self-confidence after their fear and worry have gone such that they can improve themselves, well [8]. After the story telling, the researcher ask all subjects to do self-reflection and discussion. Self-reflection is in the form of evaluation and identification of problems of the character in the story and the problem solving. This activity is purposed for improving self efication of the subject to the story that is related to their problems, i.e. communication apprehension.

After the subjects observe and evaluate other persons experience, then they tells their own experience related to their success in communication. The researcher instructs the subjects to write their own success experiencein handling commu-nication apprehension. The researcher asks the 
subjects to discuss and comment to the stories whaich has been told by their friends. This activity is purposed for pushing verbally to subjects and motivate them for fighting their commu-nication apprehension. Then, the researcher asks the subjects to apply in determining and planning of actions when communication apprehension rising up and train them selves in real conditions. It is for observing wheter or not the method is succesfull to reduce their problems.

Another factor which can push subjects to reduce their communication apprehension is by applying the metaphor technique of healing stories in a group counseling. The group counseling would give learning experience to each individual and chance to them to express their opinion, conflict, and attention of the group. The principally a group counseling is a dynamic process of interpersonal in which the center is conscious thought and action and trained in a small group to express their own feeling in front of their friends and the counselor [11]. Interpersonal communication will give advantage to increase their understanding and self-acceptance to life values and all life targets and for learning of behavior to the better life. It is expected to reduce their worry.

After the treament, there are some changes of the subjects' behavior, such as: (i) decrease in communication apprehension, (ii) change of behavior in reflecting and evaluating themselves, and (iii) change in cognitive behavior and action in facing communication apprehension. This change will affect to the increase of their self efication. Consequently, it will decrease the communication apprehension. Bandura (1997) stated that self efication is useful for choosing action, thinking, and react for the individual.

Firstly, in choosing action, as stated by Bandura (1997), that an individual often facing any difficulty such that they must decide and take action. Their self eficataion will push them to be active in any activities. On the other hand, an individual who has low efication level will try to avoid their environment and activities and will slower the development of their competence; i.e. related to communication and interaction to others. The results of this research show that the subjects have ability to choose and show their activity with confidence for reducing their communication apprehension and to get away negative perceptions of them self to their own ability and negative perception of others. Hey can start communicate with others and active in discussion.

Secondly, it is ho big their effort and endurance. Bandura [12] wrote that self efication will determine how strong an individual to stand obstacles and to face bad experience. The stronger positive perception of an individual oabut his or her self is the stronger he or she try to solve his or her problems. Otherwise, he or she will di less effort to solve and facing his or her problems and they are easily to give up.

Thirdly, it is way of thinking and emotional reaction. The way of thinking and emotional reaction that are experiencing by persons have been influenced by the persons' opinion to their ability [4]. Persons who believe that they will face many difficulty in their environment will potentially face the big difficulty. The wrong opinion will give high emotional reaction. This will create more stress and they could not use their potential, optimally. The results of the treatment to the subjects of this research are that the subjects can improve their self efication and they have positive dreams to their ability in communication and they are able to reduce the communication apprehension [13].

\section{CONCLUSION}

The results of analysis using Paired Sample $t$ Test show that Sig. (2-tailed) or $\rho$ is less than the significant level $\alpha$ i.e. $(0.014<0.05)$. It means, H0 is rejected and H1 is accepted. Therefore, it can be concluded that the metaphor technique of healing stories has been successfully treated the subject such that they can reduce their communication apprehension.

\section{REFERENCES}

[1] A. G. Bluman, Elementary statistics: A step by step approach. McGraw-Hill Higher Education New York, 2009.

[2] D. Fitri, "Efektivitas Cognitive Behavior Therapy Untuk Menurunkan Kecemasan Berbicara Di Depan Umum Pada Mahasiwa," J. Ilm. Psikol., vol. 10, no. 1, 2017.

[3] G. L. Chesley, D. A. Gillett, and W. G. Wagner, "Verbal and nonverbal metaphor with children in counseling," J. Couns. Dev., vol. 86, no. 4, pp. 399-411, 2008.

[4] W. Donsbach, The concise encyclopedia of communication. John Wiley \& Sons, 2015

[5] W. J. Lyddon, A. L. Clay, and C. L. Sparks, "Metaphor and change in counseling," J. Couns. Dev., vol. 79, no. 3, pp. 269-274, 2001.

[6] D. C. Gordon, Therapeutic metaphors: Helping others through the looking glass. Meta Publications, 1978.

[7] J. W. Creswell and C. N. Poth, Qualitative inquiry and research design: Choosing among five approaches. Sage publications, 2017.

[8] N. Jemiparera and T. INDAH PRATIWI, "PENERAPAN TEKNIK METAFORA BERBENTUK HEALING STORIES UNTUK MENGURANGI KECEMASAN BERKOMUNIKASI PADA SISWA KELAS X SMKN 8 SURABAYA," J. BK UNESA, vol. 10, no. 1, 2019.

[9] A. Bandura, "Self- efficacy," Corsini Encycl. Psychol., pp. 1-3, 2010.

[10] N. L. P. S. Aryani, N. K. Suarni, D. A. W. M. Putri, and S. Ps, "Penerapan Konseling Behavioral dengan Teknik Desensitisasi Sistematis untuk Meminimalisasi Kecemasan Siswa dalam Menyampaikan Pendapat Kelas VIII 10 SMP Negeri 2 Singaraja Tahun Pelajaran 2013/2014,” J. Ilm. Bimbing. Konseling Undiksha, vol. 2, no. $1,2014$.

[11] K. Kartono, "Patologi sosial 3: Gangguan-gangguan kejiwaan," Jakarta PT. Raja Graf. Persada, 2003.

[12] A. Bandura, Self-efficacy in changing societies. Cambridge university press, 1995.

[13] G. W. Burns, 101 healing stories for kids and teens: Using metaphors in therapy. John Wiley \& Sons, 2012. 